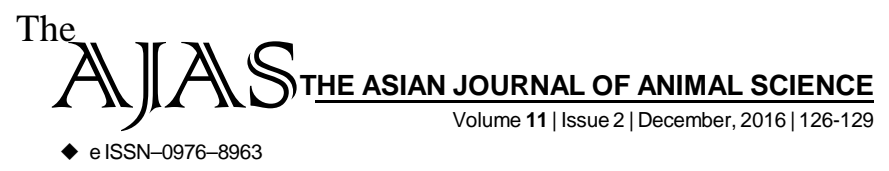

DOI : 10.15740/HAS/TAJAS/11.2/126-129 Visit us | www.researchjournal.co.in

RESEARCH ARTICLE........

\title{
Effect of crop residue based complete feed on nutrient intake and digestibility in crossbred calves
}

\author{
Z.U. RAHMAN, K.R. MITKARI AND S.P. POUL

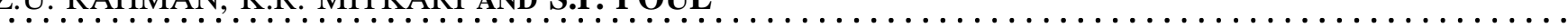

Author for Corresponding -

\section{S.P. POUL}

Department of Animal Science and Dairy Science, Vasantrao

Naik Marathwada Krishi

Vidyapeeth, PARBHANI (M.S.)

INDIA

Email: poul_s@ rediffmail.com

See end of the article for

Coopted authors'

\begin{abstract}
The present investigation was undertaken to study the effect of crop residue based complete feed on growth performance, nutrient digestibility in crossbred calves. Eighteen crossbred (HF x Deoni) calves of six to eighteen months were selected and distributed in three groups. In control treatment $\left(\mathrm{T}_{0}\right)$, the sorghum straw and concentrate used separately, in $\mathrm{T}_{1}$ treatment sorghum straw and concentrate used as complete feed whereas in $\mathrm{T}_{3}$ treatment sorghum and wheat straw in equal proportion (1:1) to form complete feed. The roughages to concentrate ratio in each treatment was maintained at 60:40 proportion. The average DM intake per $100 \mathrm{~kg}$ body weight under $\mathrm{T}_{0}, \mathrm{~T}_{1}$ and $\mathrm{T}_{2}$ treatments were $1.97,2.00$ and $2.02 \mathrm{~kg}$, respectively. The digestibility for DM, CP, EE, CF and NFE under $\mathrm{T}_{2}$ treatment were $58.64 \pm$ $1.96,57.24 \pm 1.37,53.21 \pm 1.20,58.64 \pm 1.05$ and $56.82 \pm 1.10$ per cent, respectively. The digestibility co-efficient for DM, CP, EE, CF and NFE were non- significant among the groups.
\end{abstract}

KEY WORDS....... Complete feed, Digestibility, Nutrient intake, Sorghum straw, Wheat straw

HOW TO CITE THIS ARTICLE - Rahman, Z.U., Mitkari, K.R. and Poul, S.P. (2016). Effect of crop residue based complete feed on nutrient intake and digestibility in crossbred calves. Asian J. Animal Sci., 11(2): 126-129. DOI : 10.15740/HAS/TAJAS/11.2/126-129.

ARTICLE CHRONICLE - Received : 07.06.2016; Revised : 27.10.2016; Accepted : 10.11.2016 